\title{
ANALISIS PENGARUH KECERDASAN SOSIAL TERHADAP HASIL BELAJAR IPS SISWA KELAS V DI GUGUS 2 KECAMATAN PANJI
}

\author{
Gustilas Ade Setiawan 1) \\ 1) Universitas Abdurachman Saleh Situbondo \\ gustilasade.setiawan26@gmail.com
}

\begin{abstract}
ABSTRAK: Penelitian ini adalah penelitian ex-post facto yang bersifat korelasional yang bertujuan untuk mengetahui pengaruh kecerdasan Sosial terhadap hasil belajar IPS Siswa Kelas V di Gugus 2 Kecamatan Panji. Pengambilan data dilakukan dengan menggunakan dua instrumen, yaitu kuesioner kecerdasan Sosial yang terdiri atas kesadaran sosial yang dibagi antara lain Empati dasar, Penyelarasan, Ketepatan empatik, Pengertian sosial dan fasilitas sosial yang dibagi antara lain Sinkroni, Presentasi diri, Pengaruh, Kepedulian serta tes hasil belajar yang terdiri dari tes pilihan ganda. Hasil analisis inferensial menunjukkan bahwa kesadaran sosial dan fasilitas sosial berpengaruh secara signifikan terhadap hasil belajar IPS Siswa Kelas V Gugus 2 Kecamatan Panji, dengan persamaan regresi $\mathrm{Y}=27,3+0,531 \mathrm{X} 1+0,426 \mathrm{X} 2+0,315 \mathrm{X} 3+0,637 \mathrm{X} 4+0,574 \mathrm{X} 5+0,426 \mathrm{X} 6+$ $0,426 \mathrm{X} 7+0,531 \mathrm{X} 8$ dengan koefisien $\mathrm{R}=0,68$. Dari hasil analisis dapat disimpulkan bahwa kecerdasan Sosial yang terdiri atas kesadaran sosial yang dibagi antara lain Empati dasar, Penyelarasan, Ketepatan empatik, Pengertian sosial dan fasilitas sosial yang dibagi antara lain Sinkroni, Presentasi diri, Pengaruh, Kepedulian berpengaruh positif terhadap hasil belajar IPS Siswa Kelas V Gugus 2 Kecamatan Panji.
\end{abstract}

Kata kunci : Hasil Belajar IPA, Kecerdasan Sosial.

ABSTRACT: This study is a correlational ex-post facto study which aims to determine the effect of Social intelligence on Social Sciences learning outcomes of Class V Students in Cluster 2 of Panji District. Data retrieval is done by using two instruments, namely the Social intelligence questionnaire consisting of social awareness which is divided into basic Empathy, Alignment, empathic Accuracy, Definition of social and social facilities divided among others Synchrony, Self Presentation, Influence, Concern and test of learning outcomes which consists of multiple choice tests. The results of inferential analysis show that social awareness and social facilities have a significant effect on social studies learning outcomes of Students in Class V of Cluster 2 in Panji Subdistrict, with the regression equation $Y=27.3+0.531 X 1+0.426 X 2+0.315 X 3+0.637 X 4+0.574 X 5$ $+0.426 X 6+0.426 X 7+0.531 X 8$ with the coefficient $R=0.68$. From the results of the analysis it can be concluded that Social intelligence consisting of social awareness is divided among others: Basic Empathy, Alignment, empathic Accuracy, Definition of social and social facilities divided among others Synchrony, Self Presentation, Influence, Concern have positive influence on Social Sciences learning outcomes of Class Students $V$ Cluster 2 District of Panji.

Keywords: Science Learning Outcomes, Social Intelligence.

\section{PENDAHULUAN}

Secara total, pendidikan merupakan suatu sistem yang memiliki kegiatan cukup kompleks, meliputi berbagai komponen yang berkaitan satu sama lain. Jika menginginkan 
pendidikan terlaksana secara teratur, berbagai elemen (komponen) yang terlibat dalam kegiatan pendidikan perlu dikenali. Pendidikan dapat dilihat dari hubungan elemen peserta didik (siswa), pendidik (guru), dan interaksi keduanya dalam usaha pendidikan.

Praktek pendidikan di dunia persekolahan untuk mewujudkan tujuan dari pendidikan dikelola melalui proses pembelajaran. Hal ini tentu berdampak pada perubahan perilaku sebagai hasil dari pendidikan yang menekankan pada pencapaian prestasi belajar seperti yang diterapkan dalam kurikulum sekolah yang telah dikemas sebagai mata pelajaran yang harus ditempuh pada setiap jenjang tertentu. Salah satu komponen penting dalam pendidikan yaitu pada proses pembelajaran. Pada hakikatnya pembelajaran merupakan suatu proses komunikasi, yakni proses penyampaian pesan dari sumber pesan melalui saluran atau media tertentu ke penerima pesan.

Salah satu mata pelajaran yang dilaksanakan di sekolah dasar adalah mata pelajaran IPS. Pembelajaran IPS merupakan program pendidikan yang banyak mengandung muatan nilai sebagai salah satu karakteristiknya, hal ini sebagaimana yang dikemukakan oleh Mulyana dalam Gunawan (2011), bahwa Ilmu Pengetahuan Sosial (IPS) dan Humaniora merupakan dua bidang kajian yang potensial bagi pengembangan tugas-tugas pembelajaran yang kaya nilai, karakteristik ilmu yang erat kaitannya dengan kehidupan manusia dan banyak membahas tentang bagaimana manusia dapat menjalin hubungan harmonis dengan sesama, lingkungan dan Tuhan membuat dua kajian ini sangat kaya dengan sikap, nilai, moral, etika dan perilaku.

Sependapat dengan itu menurut Lasmawan (2010) pendidikan IPS di SD hendaknya lebih menekankan pada unsur pendidikan dan pembekalan pemahaman, nilai moral, dan keterampilan-keterampilan sosial pada siswa. Sehingga kelak mereka mampu menjadikan apa yang telah dipelajarinya sebagai bekal bagi dirinya untuk melanjutkan pendidikan kejenjang yang lebih tinggi.

Fakta riil di lapangan yang dilakukan di sekolah yang ada di gugus 2 Kecamatan Panji menunjukkan bahwa siswa mengalami beberapa kesulitan dalam pembelajaran IPS, seperti: a) siswa kurang dapat mengembangkan nilai dan sikap dalam kehidupan seharihari; b) pengajaran IPS dilaksanakan dalam waktu yang terbatas, sehingga tidak mungkin dapat memperkenalkan seluruh nilai-nilai kehidupan manusia kepada siswa. Dampak yang signifikan dari kesulitan dalam pembelajaran IPS yaitu hasil belajar yang tidak maksimal. Salah satu penyebabnya yaitu interaksi atau hubungan antar individu siswa, guru dan siswa dalam proses pembelajaran, seperti ada siswa yang tidak mau bekerjasama dan ada siswa yang mau bekerjasama, ada siswa yang selama berkelompok tidak aktif dan ada siswa yang aktif, dan ada siswa yang individual dan ada siswa yang suka bersosial. Permasalahan-permasalahan itu semua mencakup kemampuan siswa untuk berhubungan dengan siswa lainnya. Kemampuan berhubungan antar individu manusia dengan individu lainnya merupakan kecerdasan sosial.

Definisi kecerdasan sosial menurut Irwantoro \& Suryana (2016) adalah kemampuan menyelesaikan masalah atau produk mode yang merupakan konsekuensi 
dalam suasana budaya dan keterampilan memecahkan masalah membuat seseorang mendekati situasi dan sasaran yang harus dicapai. Goleman (2015) menjelaskan social intelligence adalah kemampuan seseorang untuk menjalin hubungan dengan orang lain. Golemen mengkategorikan unsur-unsur kecerdasan sosial ke dalam 2 kategori: 1. Kesadaran Sosial yaitu apa yang kita rasakan tentang orang lain, 2. Fasilitas Sosial yaitu apa yang akan kita lakukan dengan kesadaran itu. Orang yang memiliki kecerdasan sosial yang tinggi, mereka cenderung untuk bisa mudah memahami dan berinteraksi dengan orang lain sehingga mudah untuk bersosialisasi dengan lingkungan sekitar. Dalam konteks proses pembelajaran di kelas, siswa yang memiliki kecerdasan sosial yang tinggi lebih bisa berinteraksi dalam kelompok belajarnya, akrab dengan teman, juga mencakup kemampuan untuk memimpin, mengorganisasikan, menangani perselisihan antar teman.

Bertolak dari latar belakang di atas penulis mencoba meneliti Analisis Pengaruh Kecerdasan Sosial Terhadap Hasil Belajar IPS Siswa Kelas V di Gugus 2 Kecamatan Panji. Pertanyaan penelitian yang dijawab dalam penelitian ini apakah kecerdasan sosial terhadap hasil belajar IPS siswa kelas V di gugus 2 Kecamatan Panji?

\section{METODE PENELITIAN}

Penelitian ini mempunyai dua variabel yaitu variabel bebas dan variabel terikat. Variabel bebas dalam penelitian ini adalah Kecerdasan Sosial yang diberi simbol X dan variabel terikat dalam penelitian ini adalah Hasil Belajar IPS yang diberi simbol Y. Desain hubungan antara variabel-variabel penelitian dapat digambarkan sebagai berikut:

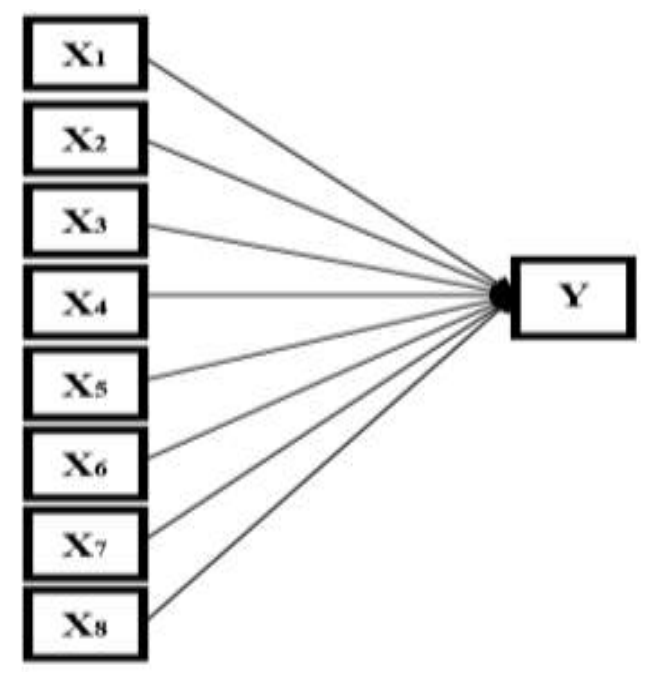

Gambar 1. Hubungan antar variable penelitian

Ket : $\mathrm{X}_{1}, \ldots \ldots . ., \mathrm{X}_{8}$ menyatakan faktor-faktor kecerdasan Sosial, $\mathrm{Y}$ menyatakan skor variabel hasil belajar IPS. Populasi dalam penelitian ini adalah seluruh siswa kelas V Gugus 2 Kecamatan Panji. Sedangkan sampel penelitian akan dipilih secara Cluster random sampling. Yaitu memilih salah satu kelas secara acak dengan asumsi bahwa 
karakteristik unit sampel homogen. Pada penelitian ini terpilih kelas V dengan jumlah siswa 40 orang.

Instrumen yang digunakan dalam penelitian berupa tes hasil belajar dan kuesioner. Tes hasil belajar digunakan untuk memperoleh skor hasil belajar IPS dan kuesioner/angket digunakan untuk mengambil data variabel kecerdasan Sosial. Kuesioner ini berbentuk skala "likert" dengan empat alternatif jawaban, yaitu : sangat sesuai (SS), cukup sesuai (CS), kurang sesuai (KS) dan tidak sesuai (TS). Kuesioner yang digunakan dalam penelitian ini adalah kuesioner yang disusun oleh Daniel Goleman selanjutnya dikembangkan sendiri oleh penulis. Tes hasil belajar dan kuesioner yang telah disusun selanjutnya diperiksa, direvisi dan dibahas secara teliti dan seksama oleh validator untuk mengetahui instrumen penelitian ini sudah memenuhi validitas konstruk dan validitas isi.

Teknik Analisis Data yaitu Statistika deskriptif digunakan untuk mendeskripsikan karakteristik skor responden untuk masing-masing variabel. Untuk keperluan tersebut digunakan tabel distribusi frekuensi dengan analisis persentase, standar deviasi, mean, nilai maksimum, nilai minimum, range (rentang skor), koefisien varians. Statistika inferensial digunakan untuk menguji hipotesis penelitian. Untuk keperluan tersebut digunakan analisis regresi, dan regresi multipel dengan memakai program komputer SPSS 13.0 dan Minitab 14 for windows. Jenis data berupa hasil belajar selanjutnya dikategorikan secara kualitatif menggunakan skala lima yang diterapkan oleh Depdikbud (Lisnawati, 2005) sebagai berikut :

1. Nilai $0-34$; dikategorikan "sangat rendah"

2. Nilai 35 - 54; dikategorikan "rendah"

3. Nilai $55-64$; dikategorikan "sedang"

4. Nilai 65 - 84; dikategorikan "tinggi"

5. Nilai 85 - 100; dikategorikan "sangat tinggi"

Sedangkan Interval kategorisasi sebagai kriteria untuk menentukan kriteria kecerdasan Sosial siswa menurut Sappaile (Rani, 2006) adalah sebagai berikut:

- Skor 0,0-5,093 dikategorikan sangat rendah

- Skor 5,094-13,336 dikategorikan rendah

- Skor 13,337 - 20,482 dikategorikan tinggi

- Skor 20,483-24,478 dikategorikan sangat tinggi

\section{HASIL DAN PEMBAHASAN}

Hasil Analisis Statistika Deskriptif 
Hasil analisis statistik deskriptif yang berhubungan dengan skor variabel hasil belajar siswa disajikan pada Tabel 1 .

Tabel 1 Statistika Deskriptif Untuk Skor Variabel Hasil Belajar IPS

\begin{tabular}{lc}
\hline \multicolumn{1}{c}{ Statistik } & Nilai Statistik \\
\hline Ukuran Sampel & 40 \\
Skor Ideal & 100 \\
Skor Tertinggi & 85,90 \\
Skor Terendah & 58,40 \\
Rentang Skor (range) & 27,50 \\
Skor Rata-rata (mean) & 72,32 \\
Simpangan Baku (standar deviasi) & 7,71 \\
Variance & 59,46 \\
\hline
\end{tabular}

Hasil analisis distribusi frekuensi dan persentase yang berhubungan dengan skor variabel hasil belajar siswa disajikan pada Tabel 2. Berdasarkan Tabel 1 dan Tabel 2, dengan memperhatikan 40 siswa sebagai sampel, 33 atau 82,5\% siswa memperoleh hasil belajar IPS berada dalam kategori tinggi dengan skor rata-rata 72,32 dan standar deviasi 7,71 dari skor ideal 100 .

abel 2. Distribusi frekuensi dan persentase skor hasil belajar siswa

\begin{tabular}{cccc}
\hline Interval (nilai) & Frekuensi & Kategori & Persentase \\
\hline $0-34$ & 0 & Sangat rendah & 0 \\
$35-54$ & 0 & Rendah & 0 \\
$55-64$ & 5 & Sedang & 12,5 \\
$65-84$ & 33 & Tinggi & 82,5 \\
$85-100$ & 2 & Sangat tinggi & 5 \\
& 40 & & 100 \\
\hline
\end{tabular}

Dengan demikian dapat disimpulkan bahwa hasil belajar IPS siswa Kelas V di Gugus 2 Kecamatan Panji berada dalam kategori tinggi. Hasil analisis statistik deskriptif yang berhubungan dengan skor variabel kecerdasan Sosial disajikan pada Tabel 3.

Tabel 3. Statistika Deskriptif Untuk Skor Variabel Kecerdasan Sosial 


\begin{tabular}{lc}
\hline \multicolumn{1}{c}{ Statistik } & Nilai Statistik \\
\hline Ukuran Sampel & 40 \\
Skor Ideal & 184 \\
Skor Tertinggi & 120,28 \\
Skor Terendah & 66,91 \\
Rentang Skor (range) & 53,37 \\
Skor Rata-rata (mean) & 90,58 \\
Simpangan Baku (standar deviasi) & 12,46 \\
Variance & 155,27 \\
\hline
\end{tabular}

Hasil analisis distribusi frekluensi yang berhubungan dengan skor variabel kecerdasan Sosial disajikan pada Tabel 4. Berdasarkan Tabel 3 dan Tabel 4, dengan memperhatikan 40 siswa sebagai sampel, 36 atau 90\% siswa memperoleh skor kecerdasan Sosial yang berada dalam kategori tinggi dengan skor rata-rata 90,58 dan standar deviasi 12,46 dengan skor ideal 184. Dengan demikian dapat simpulkan bahwa kecerdasan Sosial siswa Kelas V di Gugus 2 Kecamatan Panji memiliki kecerdasan Sosial yang tinggi.

Tabel 4. Distribusi Frekuensi Dan Persentase Untuk Skor Kecerdasan Sosial

\begin{tabular}{cccc}
\hline Interval (nilai) & Frekuensi & Kategori & Persentase \\
\hline $0,0-25,054$ & 0 & Sangat rendah & 0 \\
$25,055-67,163$ & 1 & Rendah & 2,5 \\
$67,164-107,092$ & 36 & Tinggi & 90 \\
$107,093-129,964$ & 3 & Sangat Tinggi & 7,5 \\
& 40 & & 100 \\
\hline
\end{tabular}

Hasil analisis statistik deskriptif yang berhubungan dengan skor variabel Empati dasar, dengan memperhatikan 40 siswa sebagai sampel, 31 atau 77,5\% siswa memperoleh skor Empati dasar yang berada dalam kategori tinggi dengan skor rata-rata 17,49 dan standar deviasi 2,61 dengan skor ideal 32. Hasil analisis statistik deskriptif yang berhubungan dengan skor variabel Penyelarasan dengan memperhatikan 40 siswa sebagai sampel, 37 atau 92,5\% siswa memperoleh skor Penyelarasan yang berada dalam kategori tinggi dengan skor rata-rata 11,69 dan standar deviasi 2,71 dengan skor ideal 32.

Hasil analisis statistik deskriptif yang berhubungan dengan skor variabel Ketepatan empatik, dengan memperhatikan 40 siswa sebagai sampel, 23 atau 57,5\% siswa memperoleh skor Ketepatan empatik yang berada dalam kategori tinggi dengan skor rata-rata 20,68 dan standar deviasi 3,87 dengan skor ideal 40. Hasil analisis statistik deskriptif yang berhubungan dengan skor variabel Pengertian sosial dengan memperhatikan 40 siswa sebagai sampel, 25 atau $62,5 \%$ siswa memperoleh skor 
Pengertian sosial yang berada dalam kategori tinggi dengan skor rata-rata 15,93 dan standar deviasi 4,18 dengan skor ideal 36.

Hasil analisis statistik deskriptif yang berhubungan dengan skor variabel Sinkroni, dengan memperhatikan 40 siswa sebagai sampel, 29 atau 72,5\% siswa memperoleh skor Sinkroni yang berada dalam kategori tinggi dengan skor rata-rata 24,55 dan standar deviasi 3,99 dengan skor ideal 44. Hasil analisis statistik deskriptif yang berhubungan dengan skor variabel Presentasi diri dengan memperhatikan 40 siswa sebagai sampel, 37 atau 92,5\% siswa memperoleh skor Presentasi diri yang berada dalam kategori tinggi dengan skor rata-rata 11,69 dan standar deviasi 2,71 dengan skor ideal 32.

Hasil analisis statistik deskriptif yang berhubungan dengan skor variabel Pengaruh dengan memperhatikan 40 siswa sebagai sampel, 37 atau 92,5\% siswa memperoleh skor Pengaruh yang berada dalam kategori tinggi dengan skor rata-rata 11,69 dan standar deviasi 2,71 dengan skor ideal 32. Hasil analisis statistik deskriptif yang berhubungan dengan skor variabel Kepedulian, dengan memperhatikan 40 siswa sebagai sampel, 31 atau 77,5\% siswa memperoleh skor Kepedulian yang berada dalam kategori tinggi dengan skor rata-rata 17,49 dan standar deviasi 2,61 dengan skor ideal 32.

\section{Hasil Analisis Statistik Inferensial}

\section{Uji Normalitas}

Berdasarkan hasil analisis data pada pengujian normalitas dengan analisis inferensial untuk hasil belajar, Empati dasar, Penyelarasan, Ketepatan empatik, Pengertian sosial, Sinkroni, Presentasi diri, Pengaruh, Kepedulian, P $>\alpha=0,05$ berarti tolak $\mathrm{H}_{1}$, terima $\mathrm{H}_{0}$. Yang berarti data yang diperoleh dari sampel penelitian berasal dari populasi yang berdistribusi normal.

\section{Uji Linieritas}

Pada variabel Empati dasar, Penyelarasan, Ketepatan empatik, Pengertian sosial, Sinkroni, Presentasi diri, Pengaruh, Kepedulian terhadap hasil belajar IPS, diperoleh masing-masing nilai $\mathrm{P}=0,143, \mathrm{P}=0,667, \mathrm{P}=0,549, \mathrm{P}=0,575, \mathrm{P}=$ $0,395, \mathrm{P}=0,667, \mathrm{P}=0,667$ dan $\mathrm{P}=0,143$ lebih besar dari $\alpha=0,05$, berarti tolak $\mathrm{H}_{1}$, terima $\mathrm{H}_{0}$ yang berarti ada hubungan linier antara hasil belajar dan kecerdasan Sosial.

\section{Uji Homogenitas}

Berdasarkan hasil analisis data pada pengujian homogen dengan analisis inferensial untuk Empati dasar, Penyelarasan, Ketepatan empatik, Pengertian sosial, Sinkroni, Presentasi diri, Pengaruh, Kepedulian, dan pengaruhnya terhadap hasil belajar, $\mathrm{P}=$ $0,821>\alpha=0,05$, berarti tolak $\mathrm{H}_{1}$, terima $\mathrm{H}_{0}$ yang berarti variansi data homogen. 
Pada pengujian homogenitas menggunakan Test of Constant Variance diperoleh nilai $\mathrm{P}=0,080$ untuk Empati dasar, $\mathrm{P}=0,982$ Penyelarasan, $\mathrm{P}=0,321$ untuk Ketepatan empatik, $\mathrm{P}=0,674$ untuk Pengertian sosial, $\mathrm{P}=0,724$ untuk Sinkroni dan $\mathrm{P}=0,821, \mathrm{P}=0,982$ untuk Presentasi diri, $\mathrm{P}=0,982$ untuk Pengaruh, $\mathrm{P}=$ 0,080 untuk Kepedulian. untuk kelimanya dengan $\alpha=0,05$ sehingga $\mathrm{P}>\alpha$, artinya terima Ho. Hal ini berarti bahwa sampel berasal dari populasi yang homogen.

\section{Pengujian Hipotesis}

\section{Uji hipotesis pertama}

Dari hasil analisis varians antara variabel hasil belajar, Empati dasar, Penyelarasan, Ketepatan empatik, Pengertian sosial, Sinkroni, Presentasi diri, Pengaruh, Kepedulian, diperoleh nilai propabilitas $\mathrm{P}=0,000$ dan $\mathrm{F}=14,44$. Nilai $\mathrm{F}$ adalah hasil bagi antara MS (Mean Square) untuk sumber variansi model $(315,28)$ dengan MSE (Mean Square Error) yaitu 21,84 . Jadi $\mathrm{F}=315,28 / 21,84=14,44$

Nilai F sebesar 14,44 pada nilai probabilitas $\mathrm{P}=0,000$ menunjukkan bahwa kurva distribusi F cenderung ke kanan. Nilai kritis untuk $\mathrm{F}$ diperoleh pada nilai $\mathrm{P}=\alpha$ (taraf signifikansi). Jadi, makin kecil nilai $\mathrm{P}$, maka makin besar nilai $\mathrm{F}$ yang berarti pengujian makin signifikan, dengan kata lain, $\mathrm{P}<\alpha$ jika dan hanya jika Fhitung $>\mathrm{F} \alpha$ diperoleh dari tabel distribusi F. Jadi dengan melihat hasil $\mathrm{P}=0,000$ lebih kecil $\alpha=0,05$ yang berarti bahwa pengujian signifikan, dan $\mathrm{H}_{1}$ diterima, yang berarti model regresi $\mathrm{Y}=27,3+$ $0,531 X_{1}+0,426 X_{2}+0,315 X_{3}+0,637 X_{4}+0,574 X_{5}+0,426 X_{6}+0,426 X_{7}+0,531 X_{8}$, layak secara statistis digunakan baik sebagai alat penaksir maupun sebagai peramal. Dengan $\mathrm{X}_{1}$ adalah Empati dasar, $\mathrm{X}_{2}$ adalah Penyelarasan, $\mathrm{X}_{3}$ adalah Ketepatan empatik, $\mathrm{X}_{4}$ adalah Pengertian sosial, $\mathrm{X}_{5}$ adalah Sinkroni, $\mathrm{X}_{6}$ adalah Presentasi diri, $\mathrm{X}_{7}$ adalah Pengaruh, $\mathrm{X} 8$ adalah Kepedulian yang berpengaruh terhadap hasil belajar IPS.

Pada analisis regresi, terlihat ternyata hanya variabel $\mathrm{X}_{4}$ signifikan, dengan nilai $\mathrm{P}$ $=0,012<\alpha=0,05$. Dengan nilai koefisien determinasi yang sangat tinggi $68 \%$. Berarti antara variabel bebas terjadi multikolonieritas yang menunjukkan bahwa terdapat data yang sama antara variabel bebasnya. Oleh karena itu, diambil tiga variabel yang penyebaran datanya tidak sama yaitu $\mathrm{X}_{1}$ (Empati dasar), $\mathrm{X}_{4}$ (Pengertian sosial) dan $\mathrm{X}_{8}$ (Kepedulian).

Nilai koefisien determinasi $\mathrm{R}^{2}=0,68$ menunjukkan bahwa sekitar 68,0\% variansi total hasil belajar IPS Siswa Kelas V di Gugus 2 Kecamatan Panji dapat dipengaruhi oleh Empati dasar, Penyelarasan, Ketepatan empatik, Pengertian sosial, Sinkroni, Presentasi diri, Pengaruh, Kepedulian.

\section{Uji hipotesis kedua}

Melihat hasil $\mathrm{P}=0,014$ lebih kecil dari $\alpha=0,05$ berarti pengujian signifikan, dan $\mathrm{H}_{1}$ diterima, yang berarti model regresi $\mathrm{Y}=52,4+1,14 \mathrm{X}_{1}$ layak secara statistis digunakan baik sebagai alat penaksir maupun sebagai peramal. Nilai koefisien 
determinasi $\mathrm{R}^{2}=0,149$ menunjukkan bahwa sekitar 14,9\% variansi total hasil belajar IPS Siswa Kelas V di Gugus 2 Kecamatan Panji dapat dipengaruhi oleh Empati dasar.

\section{Uji hipotesis ketiga}

Melihat hasil $\mathrm{P}=0,007$ lebih kecil dari $\alpha=0,05$ berarti pengujian signifikan, dan $\mathrm{H}_{1}$ diterima, yang berarti model regresi $\mathrm{Y}=58,4+1,19 \mathrm{X}_{2}$ layak secara statistis digunakan baik sebagai alat penaksir maupun sebagai peramal. Nilai koefisien determinasi $\mathrm{R}=0,174$ menunjukkan bahwa sekitar 17,4\% variansi total hasil belajar IPS Siswa Kelas V di Gugus 2 Kecamatan Panji dapat dipengaruhi oleh Penyelarasan.

\section{Uji hipotesis keempat}

Melihat hasil $\mathrm{P}=0,000$ lebih kecil dari $\alpha=0,05$ berarti pengujian signifikan, dan $\mathrm{H}_{1}$ diterima, yang berarti model regresi $\mathrm{Y}=43,8+1,38 \mathrm{X}_{3}$ layak secara statistis digunakan baik sebagai alat penaksir maupun sebagai peramal. Nilai koefisien determinasi $\mathrm{R}=0,478$ menunjukkan bahwa sekitar 47,8\% variansi total hasil belajar IPS Siswa Kelas V di Gugus 2 Kecamatan Panji dapat dipengaruhi oleh Ketepatan empatik.

\section{Uji hipotesis kelima}

Melihat hasil $\mathrm{P}=0,000$ lebih kecil dari $\alpha=0,05$ berarti pengujian signifikan, dan $\mathrm{H} 1$ diterima, yang berarti model regresi $\mathrm{Y}=52,7+1,23 \mathrm{X}_{4}$ layak secara statistis digunakan baik sebagai alat penaksir maupun sebagai peramal. Nilai koefisien determinasi $\mathrm{R}=0,445$ menunjukkan bahwa sekitar 44,5\% variansi total hasil belajar IPS Siswa Kelas V di Gugus 2 Kecamatan Panji dapat dipengaruhi oleh Pengertian sosial.

\section{Uji hipotesis keenam}

Melihat hasil $\mathrm{P}=0,000$ lebih kecil dari $\alpha=0,05$ berarti pengujian signifikan, dan $\mathrm{H}_{1}$ diterima, yang berarti model regresi $\mathrm{Y}=39,1+1,36 \mathrm{X}_{5}$ layak secara statistis digunakan baik sebagai alat penaksir maupun sebagai peramal. Nilai koefisien determinasi $\mathrm{R}=$ 0,492 menunjukkan bahwa sekitar 49,2\% variansi total hasil belajar IPS Siswa Kelas V di Gugus 2 Kecamatan Panji dapat dipengaruhi oleh Sinkroni.

\section{Uji hipotesis ketujuh}

Melihat hasil $\mathrm{P}=0,007$ lebih kecil dari $\alpha=0,05$ berarti pengujian signifikan, dan $\mathrm{H}_{1}$ diterima, yang berarti model regresi $\mathrm{Y}=58,4+1,19 \mathrm{X}_{6}$ layak secara statistis digunakan baik sebagai alat penaksir maupun sebagai peramal. Nilai koefisien determinasi $\mathrm{R}=0,174$ menunjukkan bahwa sekitar 17,4\% variansi total hasil belajar IPS Siswa Kelas V di Gugus 2 Kecamatan Panji dapat dipengaruhi oleh Presentasi diri.

\section{Uji hipotesis kedelapan}

Melihat hasil $\mathrm{P}=0,007$ lebih kecil dari $\alpha=0,05$ berarti pengujian signifikan, dan $\mathrm{H}_{1}$ diterima, yang berarti model regresi $\mathrm{Y}=58,4+1,19 \mathrm{X}_{7}$ layak secara statistis digunakan baik sebagai alat penaksir maupun sebagai peramal. Nilai koefisien determinasi $\mathrm{R}=0,174$ menunjukkan bahwa sekitar 17,4\% variansi total hasil belajar IPS Siswa Kelas V di Gugus 2 Kecamatan Panji dapat dipengaruhi oleh Pengaruh. 


\section{Uji hipotesis kesembilan}

Melihat hasil $\mathrm{P}=0,014$ lebih kecil dari $\alpha=0,05$ berarti pengujian signifikan, dan $\mathrm{H}_{1}$ diterima, yang berarti model regresi $\mathrm{Y}=52,4+1,14 \mathrm{X}_{8}$ layak secara statistis digunakan baik sebagai alat penaksir maupun sebagai peramal. Nilai koefisien determinasi $\mathrm{R}^{2}=0,149$ menunjukkan bahwa sekitar 14,9\% variansi total hasil belajar IPS Siswa Kelas V di Gugus 2 Kecamatan Panji dapat dipengaruhi oleh Kepedulian.

\section{Pembahasan Hasl Penelitian}

Kecerdasan sosial tidak lain adalah sesuatu yang berkaitan dengan karakteristik pribadi seseorang. Mengenai bagaimana seseorang dapat menjalin hubungan dan berinteraksi dengan orang lain. Oleh karena itu, Kecerdasan sosial sangat berperan penting dalam keberhasilan hidup seseorang termasuk pada diri seorang siswa. Seorang siswa yang tidak dapat mengontrol diri, tidak bersikap empati kepada sesama teman, maka oranglain tidak akan menyukainya walaupun memiliki IQ yang tinggi. Dan hal ini sangat berdampak pada kesuksesan seseorang dalam belajar dilingkungan sekolah pada khususnya. Hasil analisis inferensial menunjukkan bahwa kecerdasan sosial berpengaruh positif terhadap hasil belajar IPS. Temuan ini mendukung berbagai teori yang telah diuraikan pada tinjauan pustaka, bahwa kecerdasan sosial yang terdiri atas dimensi Empati dasar, Penyelarasan, Ketepatan empatik, Pengertian sosial, Sinkroni, Presentasi diri, Pengaruh, Kepedulian akan berpengaruh terhadap kesuksesan hidup yang dialaminya. Hasil belajar IPS Siswa Kelas V di Gugus 2 Kecamatan Panji yang dijadikan sampel penelitian dengan skor rata-rata 72,32 dengan distribusi frekuensi 82,5\% atau 33 orang siswa berada dalam kategori tinggi. Hal ini dapat pula memberikan motivasi kepada siswa untuk tetap meningkatkan hasil belajarnya serta memberikan sumbangsi bagi guru untuk melakukan upaya-upaya peningkatan hasil belajar IPS yang lebih tinggi lagi di masa yang akan datang. Pada penelitian ini, terlihat bahwa pada analisis regresi secara bersama-sama, hanya $\mathrm{X}_{4}$ yang signifikan. Ini berati, variabel Pengertian sosial sangat besar pengaruhnya terhadap hasil belajar yang sekaligus dapat mewakili variabel lainnya. Kecerdasan sosial Siswa Kelas V di Gugus 2 Kecamatan Panji yang dijadikan sampel penelitian dengan skor rata-rata 90,58 dengan distribusi frekuensi 90\% atau 36 orang siswa berada dalam kategori tinggi. Ini menunjukkan bahwa kecerdasan sosial Siswa Kelas V di Gugus 2 Kecamatan Panji tergolong tinggi. Sehingga kecerdasan sosial berpengaruh terhadap hasil belajar IPS Siswa Kelas V di Gugus 2 Kecamatan Panji pada taraf signifikansi $\alpha=0,05$ dengan nilai koefisien determinasi 68,0\%. Temuan ini sejalan dengan temuan yang dilakukan oleh Manualang (2015) yang mengatakan terdapat pengaruh yang signifikan kecerdasan sosial terhadap prestasi belajar siswa. 


\section{KESIMPULAN}

Berdasarkan uraian pembahasan maka dari penelitian ini dapat disimpulkan sebagai berikut: (1) Hasil belajar IPS siswa kelas V di Gugus 2 Kecamatan Panji berada pada kategori tinggi. (2) Kecerdasan Sosial siswa kelas V di Gugus 2 Kecamatan Panji berada pada kategori tinggi. (3) Kesadaran diri, pengaturan diri, motivasi diri, empati dan keterampilan sosial berpengaruh terhadap hasil belajar IPS siswa kelas V di Gugus 2 Kecamatan Panji.

Setelah melaksanakan dan melihat hasil penelitian yang diperoleh maka dapat dikemukakan beberapa saran sebagai berikut: (1) Dalam upaya peningkatan hasil belajar IPS di semua jenjang pendidikan dan khususnya di jenjang sekolah dasar umum, salah satu upaya yang dapat dilakukan adalah menumbuhkan dan meningkatkan kecerdasan Sosial yang tinggi dalam diri siswa. (2) Bagi para guru kelas agar berusaha menumbuhkan dalam diri siswa yang diajarnya tentang kecerdasan sosial yang positif. (3) Penelitian ini sangat terbatas, baik dari segi jumlah variabel maupun dari segi populasinya, sehingga disarankan kepada para peneliti di bidang pendidikan khususnya pendidikan IPS untuk melakukan penelitian lebih lanjut guna memperluas hasil-hasil penelitian ini.

\section{DAFTAR RUJUKAN}

Goleman, D. 2015. Social Intelligence Ilmu Baru Tentang Hubungan Antar Manusia. Jakarta: PT Gramedia.

Gunawan, Rudi. 2011. Pendidikan IPS Filosofi, Konsep dan Aplikasi. Bandung: Alfabeta

Irwanto \& Surayana. 2016. Kompetensi Pedagogik Untuk Peningkatan dan Penilaian Kinerja Guru dalam Rangka Implementasi Kurikulum Nasional. Sidoarjo: Genta Group Production.

Lasmawan, W. 2010. Menelisik pendidikan IPS dalam perspektif kontekstual empiris. Singaraja: Mediakom Indonesia Press Bali.

Manualang, R.A. 2015. Pengaruh Kecerdasan Sosial Terhadap Prestasi Belajar Siswa di SMK Negeri 2 Kota Jambi. Jurnal Ilmiah Universitas Batanghari Jambi Vol.15 No.3 Tahun 2015 
Volume 3, Nomor 2, Agustus 2019 